\title{
PENGARUH LATAR BELAKANG SOSIAL EKONOMI ORANG TUA TERHADAP PRESTASI BELAJAR YANG DIMEDIASI OLEH FASILITAS BELAJAR
}

\author{
Akhmad Suyono \\ FKIP Universitas Islam Riau \\ jumiati_1606@yahoo.com
}

\begin{abstract}
This research aimed to examine the effect of socio-economic background of parents on student achivement which learning facilities as intervening variable. The population of this research are 167 students and the sample are 100 students. Sampling methode used proportional random sampling. Data collection is done by questionare and it is analyzed by using path analysis. The result showed that (1) there are significant effect between sosio-economic background of parents on learning facilities; (2) there are significant effect between learning facilities on student achivement; (3) there are significant direct effect between sosio-economic background of parents on student achievement; (4) and there are significant direct effect between sosio-economic background of parents on student achievement mediated by learning facilities.
\end{abstract}

Keywords: Socio-economic Background of Parents, Learning Facilities, Student Achivement

\begin{abstract}
Abstrak: Penelitian ini bertujuan untuk menguji pengaruh latar belakang sosial ekonomi orang tua terhadap prestasi belajar siswa yang dimediasi oleh fasilitas belajar. Populasi dari penelitian ini sebanyak 167 siswa dimana sampelnya sebanyak 100 siswa. Metode penyampelan yang digunakan adalah proporsional random sampling. Data dikumpulkan menggunakan kuesioner dan dianalisis menggunakan path analysis. Hasil penelitian menunjukkan bahwa (1) terdapat pengaruh yang signifikan antara latar belakang sosial ekonomi orang tua terhadap fasilitas belajar; (2) terdapat pengaruh yang signifikan antara fasilitas belajar terhadap prestasi belajar; (3) terdapat pengaruh langsung antara latar belakang sosial ekonomi keluarga dengan prestasi belajar siswa; (4) terdapat pengaruh tidak langsung antara latar belakang sosial ekonomi orang tua terhadap prestasi belajar siswa yang dimediasi oleh fasilitas belajar.
\end{abstract}

Kata kunci: Latar Belakang Sosial Ekonomi Keluarga, Fasilitas Belajar, Prestasi Belajar

Pendidikan memiliki peranan yang sangat penting bagi perkembangan pengetahuan seseorang. Keberhasilan pendidikan seseorang sangat dipengaruhi oleh beberapa faktor antara lain bakat dan kecerdasan anak tersebut, kegiatan proses belajar mengajar di sekolah, lingkungan keluarga maupun lingkungan sekitarnya. Selain pendidikan formal 
yang dilakukan di sekolah, pendidikan juga perlu ditanamkan sejak dini dalam keluarga. Pendidikan keluarga merupakan sumber pendidikan yang utama karena segala sesuatu tentang pengetahuan dan kecerdasan manusia pertama kali diperoleh dari orang tua dan anggota keluarga sendiri. Keluarga seringkali disebut sebagai lingkungan pertama, sebab dalam lingkungan inilah pertama-tama anak mendapatkan pendidikan, bimbingan, asuhan, pembiasaan dan latihan. Bukan hanya menjadi tempat anak dipelihara dan dibesarkan, tetapi juga tempat anak hidup dan dididik pertama kali (Sukmadinata, 2004: $6)$.

Permasalahan ekonomi dalam keluarga akan sangat mengganggu kelancaran pendidikan bagi seorang anak. Banyak siswa yang terpaksa berhenti sekolah karena masalah biaya dan mereka harus mencari pekerjaan untuk membantu orang tua memenuhi kebutuhan hidup. Hal ini terjadi karena mereka tidak mampu membiayai sekolah dan membeli buku-buku pelajaran. Hamalik (2002:82) mengatakan bahwa tingkat pendidikan orang tua, tingkat ekonomi, sikap keluarga terhadap masalahmasalah sosial, realita kehidupan dan lain-lain merupakan faktor yang akan memberi pengalaman kepada anak dan menimbulkan perbedaan dalam minat, apresiasi sikap dan pemahaman ekonomis, perbendaharaan bahasa, abilitas berkomunikasi dengan orang lain, motif berfikir, kebiasaan berbicara dan pola hubungan kerjasama dengan orang lain. Perbedaan-perbedaan ini akan sangat berpengaruh dalam tingkah laku dan perbuatan dalam kegiatan belajar mengajar di sekolah.

Keterbatasan dana yang dimiliki oleh orang tua siswa kemungkinan dapat berpengaruh terhadap prestasi belajar siswa karena tidak tersedianya fasilitas belajar yang memadi. Penyediaan fasilitas belajar di rumah sangat memudahkan siswa dalam mencapai prestasi yang diharapkan, hasil belajar yang telah dijalani selama proses belajar sangat penting fungsinya untuk menentukan langkah selanjutnya dimasa yang akan datang sehingga siswa akan semaksimal mungkin mendapatkan nilai yang baik.

Syaifullah (1981) mengemukakan bahwa status sosial orang tua pada suatu ketika dapat menentukan sikap mereka terhadap pendidikan dan status ekonomi menentukan kemampuan keluarga dalam menyediakan fasilitas belajar yang diperlukan anak dalam menelaah bahan pelajaran disekolah. Lebih lanjut, Prestel dalam Aini (2007) mengatakan bahwa prestasi anak-anak dalam keluarga yang rendah status sosial ekonominya pada akhir kelas pertama lebih tinggi dari pada prestasi anak-anak daripada 
keluarga dengan status ekonominya yang mencukupi. Hal ini terjadi karena anak-anak dilatar belakang belakang sosial ekonomi yang rendah lebih cepat menyesuaikan dirinya dengan sebuah tugas atau pekerjaan yang baru, dari pada anak-anak dari latar belakang sosial ekonomi yang mencukupi.

Hasil penelitian Susilowati (2007) menunjukkan adanya faktor lain selain variabel yang diteliti yang berpengaruh terhadap prestasi belajar siswa. Penelitian ini dimaksudkan untuk menindaklanjuti penelitian yang dilakukan oleh Susilowati (2007) karena peneliti merasa tertarik untuk melakukan penelitian ulang dengan cara memasukkan faktor lain yang berpengaruh terhadap prestasi belajar siswa, yaitu dengan cara mengganti variabel motivasi dengan fasilitas belajar siswa. Selain itu, dalam penelitian yang dilakukan oleh Susilowati (2007) ditemukan kekurangan, diantaranya dalam penentuan populasi sebagai objek penelitian, peneliti hanya mengambil populasi dari kelas 2 saja sehingga data yang dihasilkan kurang mewakili karakteristik yang ada pada sekolah tersebut. Penelitian ini termotivasi untuk memperbaiki penelitian Susilowati (2007) dengan memperluas populasi dari kelas 2 dan 3 yang nantinya akan dapat mewakili karakteristik yang sebenarnya.

Berdasarkan latar belakang permasalahan yang telah dipaparkan di atas maka dihipotesiskan sebagai berikut:

$\mathrm{H}_{1}$ : Terdapat pengaruh latar belakang sosial ekonomi orang tua siswa terhadap fasilitas belajar

$\mathrm{H}_{2}$ : Terdapat pengaruh langsung latar belakang sosial ekonomi orang tua siswa terhadap prestasi belajar

$\mathrm{H}_{3}$ : Terdapat pengaruh fasilitas belajar terhadap prestasi belajar siswa

$\mathrm{H}_{4}$ : Terdapat pengaruh tidak langsung latar belakang sosial ekonomi orang tua siswa terhadap prestasi belajar yang dimediasi oleh fasilitas belajar

Hubungan variabel bebas dan terikat dapat dilihat pada Gambar 1 dibawah ini:

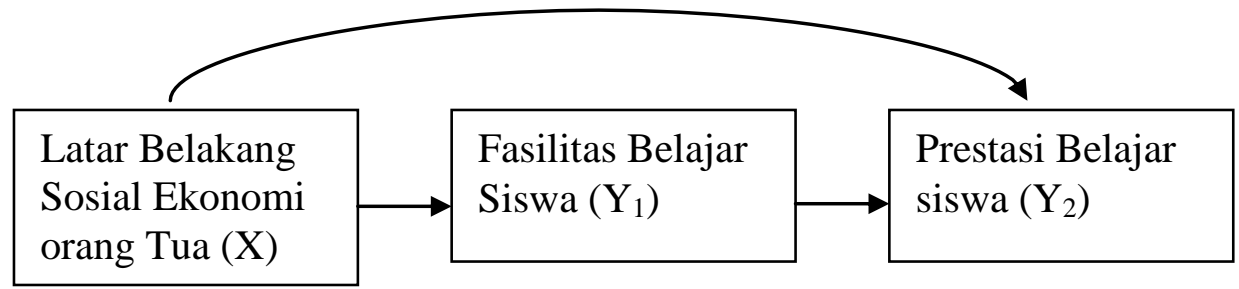

Gambar 1. Hubungan Variabel Bebas dan Terikat 


\section{METODE}

Penelitian ini dikategorikan sebagai explanatory research, yaitu penelitian yang bertujuan menjelaskan hubungan kausal antara variabel-variabel melalui pengujian hipotesis. Penelitian ini dilakukan dengan cara menjelaskan gejala yang timbul oleh suatu objek penelitian. Populasi penelitian ini adalah semua siswa-siswi jurusan Akuntansi SMK Negeri 1 Turen Malang yang berjumlah 167 siswa. Sampel yang diambil dalam penelitian ini sebanyak 100 siswa. Sampel sebanyak 100 siswa dianggap sudah mewakili dari jumlah 167 siswa jurusan Akuntansi SMK Negeri I Turen, karena jumlah 100 siswa sudah lebih dari 42 atau $25 \%$ tolal populasi yang nantinya dapat menghasilkan data yang representatif (Arikunto, 2002).

Tabel 1. Proporsi Penghitungan Sampel

\begin{tabular}{lccc}
\hline No. & Kelas & Persen $(\%)$ & $\begin{array}{c}\text { Jumlah } \\
\text { siswa }\end{array}$ \\
\hline 1 & 2 AK 1 & $44 / 167 \times 100=26,34$ & $26^{*}$ \\
2 & 2 AK 2 & $43 / 167 \times 100=25,74$ & $26^{*}$ \\
3 & 3 AK 1 & $40 / 167 \times 100=23,95$ & $24^{*}$ \\
4 & 3 AK 2 & $40 / 167 \times 100=23,95$ & $24^{*}$ \\
\hline & & Jumlah & 100 \\
\hline
\end{tabular}

Sumber: (data diolah)

Keterangan: * angka dibulatkan ke atas

Pengukuran variabel dikembangkan dari indikator yang terdapat pada jabaran variabel, ditransformasikan menjadi item-item pertanyaan. Kemudian pertanyaan terstruktur disusun sesuai dengan variabelnya melalui angket atau kueisioner untuk memperoleh data primer. Sedangkan dokumentasi merupakan data sekunder untuk melengkapi data primer yaitu mengenai nilai pelajaran seluruh bidang studi siswa berdasarkan nilai rapor.

Untuk mengumpulkan data tentang latar belakang sosial ekonomi orang tua siswa dan fasilitas belajar digunakan kuesioner berupa beberapa pertanyaan yang mengungkap tolok ukur mengenai keadaan latar belakang sosial ekonomi orang tua dan fasilitas belajar. Adapun cara pemberian skor pada setiap jawaban item pertanyaan yang diberikan kepada responden mempunyai nilai sebagai berikut: pilihan jawaban A mempunyai bobot nilai 5, pilihan jawaban B mempunyai bobot nilai 4, pilihan jawaban C mempunyai bobot nilai 3, pilihan jawaban D mempunyai bobot nilai 2 dan pilihan jawaban E mempunyai bobot nilai 1 
Dibawah ini merupakan jabaran variabel dan indikator yang dijadikan sebagai acuan untuk membuat item-item pertanyaan.

\section{Tabel 2. Jabaran Variabel}

\begin{tabular}{|c|c|c|}
\hline Variabel & Sub Variabel & Indikator \\
\hline $\begin{array}{l}\text { Variabel bebas: } \\
\text { Latar Belakang } \\
\text { Sosial Ekonomi }\end{array}$ & $\begin{array}{l}\text { Latar belakang sosial } \\
\text { orang tua siswa }\end{array}$ & $\begin{array}{l}\text { a. Tingkat pendidikan orang tua } \\
\text { b. Pekerjaan orang tua }\end{array}$ \\
\hline $\begin{array}{l}\text { Orang Tua Siswa } \\
\text { (X) }\end{array}$ & $\begin{array}{l}\text { Latar belakang ekonomi } \\
\text { orang tua siswa }\end{array}$ & $\begin{array}{l}\text { a. Tingkat pendapatan orang tua } \\
\text { b. Jumlah tanggungan orang tua }\end{array}$ \\
\hline $\begin{array}{l}\text { Variabel terikat: } \\
\text { Fasilitas Belajar } \\
\left(\mathrm{Y}_{1)}\right.\end{array}$ & Fasilitas Belajar & $\begin{array}{l}\text { a. Kepustakaan } \\
\text { b. Alat perlengkapan belajar } \\
\text { c. Ruang / tempat belajar }\end{array}$ \\
\hline $\begin{array}{l}\text { Variabel terikat: } \\
\text { Prestasi Belajar } \\
\left(\mathrm{Y}_{2)}\right.\end{array}$ & $\begin{array}{l}\text { Prestasi belajar siswa kelas } \\
2 \text { dan } 3\end{array}$ & Nilai rapor siswa \\
\hline
\end{tabular}

\section{HASIL DAN PEMBAHASAN}

Hasil

Berdasarkan hasil analisis data statistik deskriptif terhadap latar belakang sosial ekonomi orang tua siswa diperoleh nilai rata-rata 19,52 dengan standar deviasi 4,69. Nilai tersebut memberikan gambaran secara umum bahwa rata-rata latar belakang sosial ekonomi orang tua siswa adalah cukup rendah.

Hasil analisis data dengan menggunakan tingkat signifikansi 5\% menunjukkan bahwa pengaruh lansung antara latar belakang sosial ekonomi orang tua $(\mathrm{X})$ terhadap fasilitas belajar siswa $\left(\mathrm{Y}_{1}\right)$ diperoleh nilai $\mathrm{t}_{\text {hitung }}=5,963$ dengan $\mathrm{t}_{\text {tabel }}=1,984$. Jadi $\mathrm{t}_{\text {hitung }}$ $>\mathrm{t}_{\text {tabel, }}$ sehingga $\mathrm{H}_{0}$ yang menyatakan tidak ada pengaruh langsung antara latar belakang sosial ekonomi orang tua $(\mathrm{X})$ terhadap fasilitas belajar siswa $\left(\mathrm{Y}_{1}\right)$ ditolak dan Ha yang menyatakan ada pengaruh langsung antara latar belakang sosial ekonomi orang tua (X) terhadap fasilitas belajar siswa $\left(\mathrm{Y}_{1}\right)$ diterima.

Koefisien $\left(\mathrm{R}^{2}\right)$ adalah sebesar 0,266 yang berarti $26,6 \%$ perubahan variabel fasilitas belajar siswa disebabkan oleh perubahan latar belakang sosial ekonomi orang tua sedangkan sisanya sebesar $73,4 \%$ disebabkan oleh faktor lain yang tidak terdapat dalam persamaan. Nilai koefisien beta terstandarisasi sebesar 0,516 menunjukkan 
bahwa terdapat korelasi atau hubungan yang agak rendah antara latar belakang sosial ekonomi orang tua $(\mathrm{X})$ terhadap fasilitas belajar siswa $\left(\mathrm{Y}_{1}\right)$.

Hasil analisis statistik deskriptif terhadap fasilitas belajar siswa diperoleh nilai rata-rata 18,01 dengan standar deviasi 4,30. Nilai tersebut memberikan gambaran secara umum bahwa rata-rata fasilitas belajar siswa adalah kurang mendukung. Dari analisis data statistik deskriptif terhadap prestasi belajar siswa diperoleh nilai rata-rata 74,57 dengan standar deviasi 4,.20. Berdasarkan distribusi tersebut diatas memberikan gambaran secara umum bahwa rata-rata prestasi belajar siswa adalah cukup.

Hasil analisis data dengan menggunakan tingkat signifikansi 5\% menunjukkan bahwa pengaruh lansung antara latar belakang sosial ekonomi orang tua $(\mathrm{X})$ terhadap prestasi belajar siswa $\left(\mathrm{Y}_{2}\right)$ diperoleh nilai $\mathrm{t}_{\text {hitung }}=3,473$ dengan $\mathrm{t}_{\text {tabel }}=1,984$. Jadi $\mathrm{t}_{\text {hitung }}$ $>t_{\text {tabel, }}$ sehingga $\mathrm{H}_{0}$ yang menyatakan tidak ada pengaruh langsung antara latar belakang sosial ekonomi orang tua $(\mathrm{X})$ terhadap prestasi belajar siswa $\left(\mathrm{Y}_{2}\right)$ ditolak dan Ha yang menyatakan ada pengaruh langsung antara latar belakang sosial ekonomi orang tua (X) terhadap prestasi belajar siswa $\left(\mathrm{Y}_{2}\right)$ diterima.

Sedangkan koefisien $\left(\mathrm{R}^{2}\right)$ adalah sebesar 0,108 yang berarti $10,8 \%$ perubahan variabel prestasi belajar siswa disebabkan oleh perubahan latar belakang sosial ekonomi orang tua sedangkan sisanya sebesar $89,2 \%$ disebabkan oleh faktor lain yang tidak terdapat dalam persamaan. Nilai koefisien beta terstandarisasi sebesar 0,328 menunjukkan bahwa terdapat korelasi atau hubungan yang rendah antara latar belakang sosial ekonomi orang tua $(\mathrm{X})$ terhadap prestasi belajar siswa $\left(\mathrm{Y}_{2}\right)$.

Hasil analisis data dengan menggunakan tingkat signifikansi 5\% menunjukkan bahwa pengaruh langsung antara fasilitas belajar siswa $\left(\mathrm{Y}_{1}\right)$ terhadap prestasi belajar siswa $\left(\mathrm{Y}_{2}\right)$ diperoleh nilai $\mathrm{t}_{\text {hitung }}=3,354$ dengan $\mathrm{t}_{\text {tabel }}=1,984$. jadi $\mathrm{t}_{\text {hitung }}>\mathrm{t}_{\text {tabel, }}$, sehingga $\mathrm{H}_{0}$ yang menyatakan tidak ada pengaruh langsung antara fasilitas belajar $\left(\mathrm{Y}_{1}\right)$ terhadap prestasi belajar siswa $\left(\mathrm{Y}_{2}\right)$ ditolak dan Ha yang menyatakan ada pengaruh langsung antara fasilitas belajar $\left(\mathrm{Y}_{1}\right)$ terhadap prestasi belajar siswa $\left(\mathrm{Y}_{2}\right)$ diterima.

Sedangkan koefisien $\left(\mathrm{R}^{2}\right)$ adalah sebesar 0,103 yang berarti $10,3 \%$ perubahan variabel prestasi belajar siswa disebabkan oleh perubahan fasilitas belajar siswa sedangkan sisanya sebesar $89,7 \%$ disebabkan oleh faktor lain yang tidak terdapat dalam persamaan. Nilai koefisien beta terstandarisasi sebesar 0,321 menunjukkan bahwa 
terdapat korelasi atau hubungan yang rendah antara fasilitas belajar siswa $\left(\mathrm{Y}_{1}\right)$ terhadap prestasi belajar siswa $\left(\mathrm{Y}_{2}\right)$.

Setelah mengetahui pengaruh secara langsung dari masing-masing variabel bebas terhadap variabel terikat pada model persamaan pertama dan kedua, maka selanjutnya dihitung pengaruh tidak langsung dan total variabel latar belakang sosial ekonomi orang tua $(\mathrm{X})$ terhadap prestasi belajar siswa $\left(\mathrm{Y}_{2}\right)$ melalui variabel intervening fasilitas belajar siswa ( $\left.\mathrm{Y}_{1}\right)$ (Riduwan dan Kuncoro, 2007). Untuk memudahkannya terlebih dahulu disusun model lintasan dalam analisis jalur sebagai berikut:

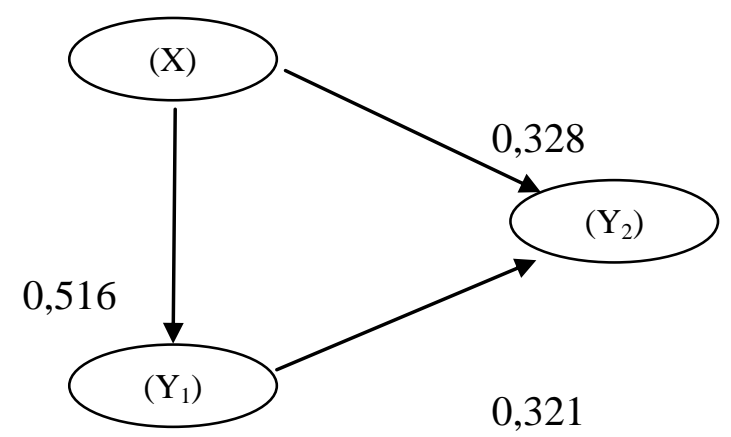

\section{Gambar 2. Model lintasan jalur}

Pengaruh tidak langsung variabel bebas terhadap variabel terikat melalui variabel intervening seperti model diatas diperoleh melalui perkalian nilai pengaruh langsung (koefisien beta terstandarisasi) pada masing-masing persamaan. Dibawah ini adalah ringkasan dari koefisien jalur, pengaruh langsung, pengaruh tidak langsung dan pengaruh total sebagai berikut:

Tabel 3. Koefisien Jalur, Pengaruh Lansung, tidak Langsung dan Pengaruh Total

\begin{tabular}{lllll}
\hline No & Keterangan Jalur & & Pengaruh Kausal & \\
\hline & & Langsung & Tidak langsung melalui $\left(\mathbf{Y}_{\mathbf{1}}\right)$ & Total \\
& & & & \\
1 & $\mathrm{X} \rightarrow \mathrm{Y} 1$ & 0,516 & - & 0,516 \\
2 & $\mathrm{Y} 1 \rightarrow \mathrm{Y} 2$ & 0,321 & - & 0,321 \\
3 & $\mathrm{X} \rightarrow \mathrm{Y} 2$ & 0,328 & - & 0,328 \\
\hline 4 & $\mathrm{X} \rightarrow \mathrm{Y} 1 \rightarrow \mathrm{Y} 2$ & 0,328 & 0,166 & 0,494 \\
\hline
\end{tabular}

Sumber: (Data diolah)

Berdasarkan tabel di atas, dapat dihitung besarnya pengaruh dari semua variabel jalur baik secara langsung, tidak langsung maupun pengaruh total serta dapat diketuhui taraf atau tinggi rendahnya hubungan antara vaariabel-variabel tersebut melalui nilai koefisien beta pengaruh tidak langsung latar belakang sosial ekonomi 
orang tua $(\mathrm{X})$ terhadap prestasi belajar $\left(\mathrm{Y}_{2}\right)$ melalui fasilitas belajar $\left(\mathrm{Y}_{1}\right)$, melalui perkalian koefisien beta terstandarisasi antara latar belakang sosial ekonomi orang tua (X) dengan fasilitas belajar $\left(\mathrm{Y}_{1}\right)$ dan fasilitas belajar $\left(\mathrm{Y}_{1}\right)$ dengan prestasi belajar siswa $\left(\mathrm{Y}_{2}\right)$ yang kemudian dijumlahkan dengan nilai beta latar belakang sosial ekonomi orang tua $(\mathrm{X})$ terhadap prestasi belajar siswa $\left(\mathrm{Y}_{2}\right)$.

Dari hasil koefisien beta terstandarisasi pengaruh tidak langsung latar belakang sosial ekonomi orang tua terhadap prestasi belajar siswa melalui fasilitas belajar sebesar 0,166 ini lebih kecil jika dibandingkan dengan pengaruh latar belakang sosial ekonomi orang tua terhadap prestasi belajar siswa yang memiliki nilai sebesar 0,328 . Total nilai koefisien beta 0,494 ini menunjukkan terdapat pengaruh tidak langsung yang agak rendah antara latar belakang sosial ekonomi orang tua terhadap prestasi belajar siswa melalu fasilitas belajar.

\section{Pembahasan}

Hipotesis 1 yang menyatakan bahwa ada pengaruh secara langsung yang positif dan signifikan antara latar belakang sosial ekonomi orang tua siswa terhadap fasilitas belajar siswa diterima. Pengaruh secara langsung antara latar belakang sosial ekonomi orang tua terhadap fasilitas belajar siswa sebesar 0,516 dengan tingkat signifikansi 0,000 atau probabilitas lebih kecil dari 1 dimana hal ini dapat diartikan secara umum memiliki pengaruh yang signifikan.

Keadaan sosial ekonomi orang tua akan berpengaruh terhadap adanya fasilitas belajar bagi siswa. Hal ini disebabkan oleh kemampuan orang tua dalam menyediakan sarana atau peralatan belajar. Karena dengan tidak tersedianya sarana belajar akan dapat menyurutkan keinginan siswa untuk belajar. Syaifullah (1981:97) mengemukakan bahwa status sosial orang tua anak pada suatu ketika dapat menentukan sikap mereka terhadap pendidikan atau peranan pendidikan dalam kehidupan manusia, status ekonomis menentukan kemampuan keluarga dalam menyediakan fasilitas belajar yang diperlukan anak dalam menelaah bahan pelajaran disekolah. Pendidikan orang tua siswa kelas 2 dan 3 jurusan akuntansi SMK Negeri 1 Turen sebagian besar adalah lulusan SD dan bekerja sebagai petani, dan pada umumnya mereka mempunyai penghasilan yang tergolong rendah sehingga penyediaan fasilitas belajar bagi anak-anaknya kurang terpenuhi. 
Faktor fasilitas belajar yang diberikan orang tua pada anak-anaknya memegang peranan yang penting dalam suatu proses belajar. Jika orang tua dapat memberikan atau menyediakan fasilitas yang memadai bagi anak-anaknya, maka akan timbul dorongan dan hasrat dalam diri anak untuk belajar lebih baik. Anak akan menyadari kegunaan dan tujuan yang hendak dicapai dari suatu mata pelajaran tertentu apabila mereka memiliki fasilitas yang sangat lengkap.

Siswa yang berasal dari latar belakang sosial ekonomi orang tua rendah tidak dapat memenuhi semua fasilitas belajarnya. Sedangkan siswa yang berasal dari latar belakang sosial ekonomi tinggi semua fasilitas belajarnya terpenuhi sehingga mereka memiliki motivasi untuk belajar menjadi lebih baik. Dengan adanya fasilitas belajar yang memadai akan mendorong mereka untuk berkonsentrasi dalam belajar dan dapat mencapai cita-cita.

Hipotesis 2 yang menyatakan ada pengaruh secara langsung yang positif dan signifikan antara latar belakang sosial ekonomi orang tua siswa terhadap prestasi belajar siswa diterima. Pengaruh secara langsung antara latar belakang sosial ekonomi orang tua terhadap pretasi belajar siswa sebesar 0,328 dengan tingkat signifikansi 0,000 atau probabilitas lebih kecil dari 1 dimana hal ini dapat diartikan memiliki pengaruh yang signifikan. Keadaan sosial ekonomi keluarga dapat berperan dalam meningkatkan prestasi belajar siswa karena keluarga merupakan kelompok sosial pertama dalam kehidupan manusia dimana ia belajar dan menyatakan diri sebagai mahluk sosial di dalam hubungan interkasi dengan kelompoknya. Segala kegiatan yang dilakukan oleh anak merupakan cerminan dari apa yang telah diajarkan oleh orang tuanya. Sebagai orang tua harus dapat memotivasi anaknya agar mereka dapat belajar semaksimal mungkin agar mereka pendapatkan prestasi yang maksimal pula.

Ahmadi (2002:258) mengatakan bahwa prestasi anak-anak dalam keluarga yang rendah status sosial ekonominya pada akhir kelas pertama adalah lebih tinggi dari pada prestasi anak-anak dari keluarga status ekonominya yang mencukupi. Hal ini terjadi karena anak-anak dilatar belakang belakang sosial ekonomi yang rendah lebih cepat menyesuaikan dirinya dengan sebuah tugas atau pekerjaan yang baru, dari pada anak-anak dari latar belakang sosial ekonomi yang mencukupi.

Pendidikan orang tua yang sebagian besar adalah SD dan bekerja sebagai petani membuat mereka kurang memiliki banyak waktu untuk memperhatikan anak. 
Ada beberapa dari mereka yang tidak pernah menanyakan prestasi belajar anaknya meningkat atau bahkan menurun. Yang penting bagi mereka adalah anaknya dapat naik kelas. Selain itu juga guru berperan dalam meningkatkan prestasi belajar siswa. Guru dapat mengajar dengan menggunakan media atau menerapkan metode-metode pembelajaran konstruktivisme untuk membantu siswa memahami suatu pelajaran tertentu. Tidak semua mata pelajaran menarik bagi siswa, maka tugas guru adalah membuat semua pelajaran menjadi menarik dan menyenangkan.

Lebih lanjut, Slameto (2003:63) menyatakan bahwa keadaan ekonomi keluarga erat hubungannya dengan belajar anak. Anak yang sedang belajar selain harus terpenuhi kebutuhan pokoknya, misal makan, pakaian, perlingdungan kesehatan dan lain-lain, juga membutuhkan fasilitas belajar seperti ruang belajar, meja, kursi, penerangan, alat tulis-menulis, buku dan lain-lain. Fasilitas belajar itu hanya dapat terpenuhi jika keluarga mempunyai cukup uang. Apabila fasilitas belajar anak dapat terpenuhi, maka kegiatan belajar menjadi lancar dan tidak terhambat sehingga prestasi belajar anak menjadi meningkat karena fasilitas belajar dapat terpenuhi membuat mereka menjadi fokus dalam kegiatan belajar.

Orang tua dengan latar belakang sosial ekonominya tinggi mempengaruhi tingkat pemahaman terhadap pentingnya pendidikan bagi anak, sehingga mereka akan menciptakan suasana rumah yang kondusif terhadap kegiatan belajar anak di rumah untuk mendorong mereka agar mempunyai motivasi dalam belajar. Apabila mereka termotivasi dalam belajar, maka mereka akan mencapai prestasi yang maksimal. Latar belakang sosial ekonomi orang tua akan dapat meningkatkan prestasi belajar siswa, apabila mereka termotivasi untuk belajar, karena tanpa belajar seorang siswa tidak akan mungkin mendapatkan prestasi yang maksimal.

Hipotesis 3 yang menyatakan ada pengaruh secara langsung yang positif dan signifikan antara fasilitas belajar siswa terhadap prestasi belajar siswa diterima. Pengaruh secara langsung fasilitas belajar siswa terhadap prestasi belajar siswa sebesar 0,321 dengan tingkat signifikansi 0,000 atau probabilitas lebih kecil dari 1 dimana hal ini dapat diartikan secara umum memiliki pengaruh yang signifikan.

Berdasarkan UU Sisdiknas No. 20 tahun 2003 pasal 45 dikatakan bahwa setiap satuan pendidikan harus menyediakan fasilitas belajar atau sarana dan prasarana yang memenuhi keperluan pendidikan sesuai pertumbuhan dan perkembangan potensi fisik, 
kecerdasan intelektual, social, emosional, dan kejiwaan peserta didik. Jadi sarana dan prasarana yang lengkap sangat diperlukan sebagai faktor penunjang proses pembelajaran dan pencapaian prestasi yang baik di sekolah.

Prestasi siswa kelas 2 dan 3 jurusan akuntansi SMK Negeri 1 Turen adalah cukup. Hal ini disebabkan karena ada sebagian siswa yang tidak mau mengerjakan tugas sekolah dengan usaha sendiri dan selalu mencontek teman, selain itu ada beberapa siswa yang malas mengikuti pelajaran karena alasan tidak memiliki buku penunjang atau buku cetak. Apabila ada siswa yang tidak mampu membeli buku cetak dalam pelajaran yang bersangkutan, sebagai seorang guru harus dapat membuat mereka untuk mengukuti pelajaran dengan cara meringkas mata pelajaran yang akan diajarkan dan menyuruh siswa untuk memfoto copy agar biaya yang dikeluarkan relatif murah.

Proses belajar memerlukan fasilitas belajar yang memudahkan siswa dalam belajar sehingga dapat mencapai prestasi belajar yang maksimal, bagi siswa yang kurang mampu dalam pemenuhan fasilitas belajar jika tidak mempunyai minat yang tinggi dalam belajar tentu akan mendapat hambatan yang tinggi dalam belajar. Tentunya bagi siswa yang kurang mampu dan minat yang tinggi dalam belajar haruslah kreatif dalam memanfaatkan keterbatasan yang dimilikinya dengan memanfaatkan fasilitas belajar yang ada di sekolah.

Pengaruh tidak langsung antara latar belakang sosial ekonomi orang tua siswa terhadap prestasi belajar siswa melalui fasilitas belajar sebesar 0,166 sedangkan pengaruh secara langsung antara latar belakang sosial ekonomi orang tua terhadap prestasi belajar siswa sebesar 0,328. Hipotesis yang menyatakan ada pengaruh secara tidak langsung antara latar belakang sosial ekonomi orang tua terhadap prestasi belajar siswa melalui fasilitas belajar siswa diterima. Pengaruh tidak langsung antara latar belakang sosial ekonomi orang tua terhadap prestasi belajar melalui fasilitas belajar siswa sebesar 0,494 menunjukkan terdapat pengaruh yang cukup.

Keterbatasan dana yang dimiliki oleh orang tua siswa akan dapat berpengaruh terhadap prestasi belajar siswa. Bagi orang tua yang berlatar belakang sosial ekonomi tinggi, belum tentu prestasi belajarnya tinggi dan sebaliknya tidak jarang orang tua yang latar belakang sosial ekonominya rendah namun anaknya mampu mendapatkan prestasi yang maksimal, tetapi latar belakang sosial ekonomi orang tua siswa belum tentu menjadi salah satu faktor yang berpengaruh terhadap prestasi belajar siswa, perlu kita 
ketahui bahwa banyak faktor lain yang berpengaruh terhadap prestasi belajar siswa diantaranya adalah dukungan yang diberikan keluarga yang berupa penyediaan fasilitas belajar. Penyediaan fasilitas belajar di rumah sangat memudahkan siswa dalam mencapai prestasi yang diharapkan, hasil belajar yang telah dijalani selama proses belajar sangat penting fungsinya untuk menentukan langkah selanjutnya dimasa yang akan datang sehingga siswa akan semaksimal mungkin mendapatkan nilai yang baik. Orang tua harus memahami dan memberikan banyak waktu belajar dirumah kepada anaknya. Orang tua harus mampu menciptakan lingkungan belajar di rumah yang nyaman apabila mereka menginginkan anak-anaknya mencapai prestasi yang lebih baik.

Latar belakang sosial ekonomi orang tua akan lebih baik mempengaruhi prestasi belajar secara langsung dari pada mempengaruhi prestasi belajar secara tidak langsung melalui fasilitas belajar siswa. Pengaruh latar belakang sosial ekonomi orang tua terhadap fasilitas belajar siswa lebih tinggi dari pada pengaruh fasilitas terhadap prestasi. Latar belakang sosial ekonomi orang tua yang tinggi anak menjamin tercapainya fasilitas belajar yang cukup baik, namun lain halnya dengan pengaruh latar belakang sosial ekonomi orang tua terhadap prestasi. Latar belakang sosial ekonomi yang tinggi belum tentu prestasi belajar anaknya tinggi dan latar belakang sosial ekonomi orang tua yang rendah belum tentu prestasi yang dihasilkan juga rendah.

Pengaruh latar belakang sosial ekonomi orang tua terhadap fasilitas belajar siswa hanya $26,6 \%$. Menunjukkan bahwa pengaruh tersebut sangat rendah dan sisanya $73,4 \%$ dipengaruhi oleh variabel lain seperti perhatian orang tua, status anak dalam keluarga, suasana lingkungan keluarga dan sebagainya. Pengaruh fasilitas belajar terhadap prestasi sebesar $10,3 \%$ menunjukkan bahwa pengaruh tersebut juga sangat rendah dan sisanya $89,7 \%$ seperti strategi mengajar guru, motivasi belajar siswa, latar belakang sosial ekonomi orang tua, profesionalisme guru dan sebagainya.

Latar belakang sosial ekonomi orang tua dapat berperan dalam meningkatkan prestasi belajar siswa melalui fasilitas belajar karena orang tua merupakan kelompok sosial yang pertama dalam kehidupan manusia dimana ia belajar dan menyatakan dirinya sebagai makhlus sosial di dalam hubungan interaksi dengan lingkungannya. Segala kegiatan yang dilakukan oleh anak merupakan cerminan dari apa yang telah diajarkan oleh orang tuanya. 
Berdasarkan hasil penelitian dapat diketahui bahwa prestasi belajar dipengaruhi oleh fasilitas belajar dan fasilitas belajar dipengaruhi oleh latar belakang sosial ekonomi orang tua siswa. Hal ini menunjukkan pentingnya latar belakang sosial ekonomi orang tua yang memberikan dorongan dan kesempatan bagi anak untuk berprestasi lebih baik.

\section{SIMPULAN}

Berdasarkan hasil analisis data dan pembahasan diatas, maka dapat disimpulkan sebagai berikut: (1) terdapat pengaruh langsung secara positif dan signifikan antara latar belakang sosial ekonomi orang tua terhadap fasilitas belajar siswa kelas 2 dan 3 SMK Negeri 1 Turen; (2) terdapat pengaruh langsung secara positif dan signifikan antara latar belakang sosial ekonomi orang tua terhadap prestasi belajar siswa kelas 2 dan 3 SMK Negeri 1 Turen; (3) terdapat pengaruh langsung yang signifikan antara fasilitas belajar terhadap prestasi belajar siswa (4) terdapat pengaruh positif secara tidak langsung antara latar belakang social ekonomi orang tua terhadap prestasi belajar siswa melalui fasilitas belajar siswa kelas 2 dan 3 SMK Negeri 1 Turen. Pengaruh langsung lebih kuat dari pada pengaruh tidak langsung. Pengaruh langsung sebesar 0,328. Sedangkan pengaruh tidak langsung sebesar 0,166. Dengan demikian latar belakang social ekonomi orang tua siswa lebih tinggi mempengaruhi prestasi belajar secara langsung daripada melalui fasilitas belajar sebagai variable intervening.

\section{DAFTAR RUJUKAN}

Arikunto, Suharsimi. 2002. Prosedur Penelitian. Jakarta: Rineka Cipta

Aini. 2007. Pengaruh Latar Belakang Sosial Ekonomi Orang Tua terhadap Prestasi belajar siswa SMA Negeri 8 Malang.

Hamalik, Oemar. 2002. Psikologi Belajar Mengajar. Bandung:Sinar Baru Grasindo

Riduwan \& Engkos Achmad Kuncoro. 2007. Cara menggunakan dan memakai Analisis Jalur (Path Analysis). Bandung: Alfabeta

Slameto. 2003. Belajar dan Faktor - Faktor Yang Mempengaruhinya. Jakarta: Rineka Cipta 
Susilowati, Yeni. 2007. Pengaruh Latar Belakang Sosial Ekonomi Orang Tua Siswa terhadap Motivasi dan Dampaknya terhadap Prestasi Belajar Siswa di SMA Negeri I Sutojayan Blitar.

Sukmadinata, Nana Syaodih. 2005. Landasan Psikologi Proses Pendidikan. Bandung: Remaja Rosdakarya.

UUD 1945 dan Perubahannya Susunan Kabinet RI Lengkap. 2007. Jakarta: PT Kawan Pustaka.

Undang-Undang Republik Indonesia Nomor 20 Tahun 2003 tentang Sistem Pendidikan Nasional. 2003. Jakarta: Departemen Pendidikan Nasional. 